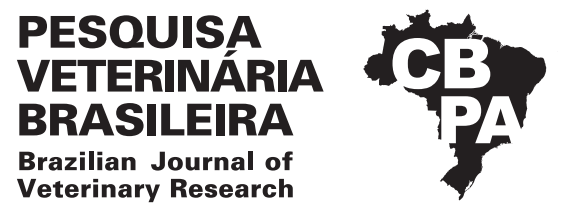

Pesq. Vet. Bras. 38(8):1675-1680, agosto 2018 DOI: $10.1590 / 1678-5150-P V B-5794$

Original Article

Animais Selvagens/Wildlife Medicine

ISSN 0100-736X (Print)

ISSN 1678-5150 (Online)

\title{
An outbreak of malignant catarrhal fever in Sambar deer (Rusa unicolor) ${ }^{1}$
}

\author{
Mariana C. Oliveira², Gabriela O. Pereira ${ }^{2}$, Yasmin Daoualibi² ${ }^{2}$, Valéria Dutra ${ }^{3}$, \\ Marilene F. Brito ${ }^{2}$, Saulo A. Caldas ${ }^{4}$, Daniel A. Balthazar ${ }^{4}$ and Daniel G. Ubiali ${ }^{2 *}$
}

\begin{abstract}
Oliveira M.C., Pereira G.O., Daoualibi Y., Dutra V., Brito M.F., Caldas S.A., Balthazar D.A. \& Ubiali D.G. 2018. An outbreak of malignant catarrhal fever in Sambar deer (Rusa unicolor). Surto de febre catarral maligna em cervos Sambar (Rusa Unicolor). Pesquisa Veterinária Brasileira 38(8):1675-1680. Setor de Anatomia Patológica, Departamento de Epidemiologia e Saúde Pública, Anexo do Instituto de Veterinária, Universidade Federal Rural do Rio de Janeiro, BR-465 Km 7, Seropédica, RJ 23890-001, Brazil. E-mail: danielubiali@hotmail.com

Malignant catarrhal fever (MCF) is an infectious, pansystemic and highly fatal disease with wide geographic distribution. The species that are clinically prone to it include cattle, deer and bison. In Brazil, the disease in ruminants and deer is associated with the contact with sheep, especially during labor, when the fetal remains that are eliminated contain the ovine herpesvirus $2(\mathrm{OvHV}-2)$. The outbreak took place in a conservationist property in the city of Casimiro de Abreu/RJ, which hosted 23 Sambar deer, and, of these, 19 died, showing neurological signs. The deer lived in a location together with 15 male and female meat sheep. A female specimen of the Sambar deer (Rusa unicolor), aged approximately three years, which had presented with neurological clinical signs was referred to necropsy in the Setor de Anatomia Patológica at Universidade Federal Rural do Rio de Janeiro (SAP/UFRRJ). During necropsy, cerebrospinal fluid was sampled for analysis; fragments of several organs were fixated in 10\% buffered formalin and processed for histopathological analysis. Fragments of occipital lobe, cerebellum and bulb were collected to perform the polymerase chain reaction (PCR). The diagnosis of this outbreak was based on epidemiological, clinical and pathological findings, and on the amplification of the OvHV-2 DNA through PCR. The histological changes were the base to confirm the MCF case and were characterized by degeneration of vascular endothelial cells, fibrinoid vasculitis, hyperplasia and necrosis of lymphoid organs. However, PCR was an important tool to confirm the diagnosis. MCF as an important disease with nervous symptomatology in deer.
\end{abstract}

INDEX TERMS: Sambar deer, Cervus unicolor, Rusa unicolor, malignant catharral fever, OvHV-2, Rhadinovirus, viroses.

RESUMO.- [Surto de febre catarral maligna em cervos Sambar (Rusa Unicolor).] A febre catarral maligna (FCM) é uma doença infecciosa, com distribuição geográfica ampla, pansistêmica e altamente fatal. As espécies clinicamente

\footnotetext{
${ }^{1}$ Received on January 31, 2018.

Accepted for publication on February 8, 2018.

${ }^{2}$ Setor de Anatomia Patológica, Departamento de Epidemiologia e Saúde Pública, Anexo I do Instituto de Veterinária, Universidade Federal Rural do Rio de Janeiro (UFRRJ), BR-465 Km 7, Seropédica, RJ 23890-000, Brazil. * Corresponding author: danielubiali@hotmail.com

${ }^{3}$ Departamento de Clínica Médica Veterinária, Universidade Federal de Mato Grosso (UFMT), Av. Fernando Corrêa da Costa 2367, Coxipó, Cuiabá, MT 78060-900, Brazil.

${ }^{4}$ Departamento de Medicina e Cirurgia Veterinária, UFRR, BR-465 Km 7, Seropédica, RJ 23890-000.
}

suscetíveis incluem bovino, cervo e bisão. No Brasil, a doença em ruminantes e cervídeos está associada ao contato com ovinos, principalmente durante o parto, no qual os envoltórios fetais eliminados contém, em suas secreções, o Herpesvírus ovino-2 (OvHV-2). O surto ocorreu em uma propriedade conservacionista no município de Casimiro de Abreu/RJ, que abrigava 23 cervos exóticos, onde foram registradas a morte de 19 destes, com sinais neurológicos. Os cervos habitavam em um piquete com 15 ovinos de corte, machos e fêmeas. Um exemplar de cervo sambar (Rusa unicolor), fêmea, com aproximadamente três anos de idade, que havia apresentado sinais clínicos neurológicos foi encaminhado para necropsia no Setor de Anatomia Patológica da Universidade Federal Rural do Rio de Janeiro (SAP/UFRRJ). Durante a necropsia foi realizada a coleta de líquido cefalorraquidiano e de fragmentos de lobo 
occipital, cerebelo e bulbo, para a realização de reação em cadeia da polimerase (PCR). Fragmentos de diversos órgãos foram fixados em formalina $10 \%$ tamponada e processados para a análise histopatológica. 0 diagnóstico do presente surto foi estabelecido com base nos achados epidemiológicos, clínicos, patológicos e na amplificação do DNA do OvHV-2 através da PCR. As alterações histológicas foram a base para confirmar o caso de FCM e caracterizaram-se por degeneração de células endoteliais vasculares, vasculite fibrinoide, hiperplasia dos órgãos linfoides. Contudo, a PCR foi uma ferramenta importante para a confirmação do diagnóstico. Ressalta-se a importância da FCM na lista dos diagnósticos diferenciais de doenças que cursam com sintomatologia nervosa em cervídeos.

TERMOS DE INDEXAÇ̃̃O: Cervo Samba, Rusa unicolor, Cervus unicolor, febre catarral maligna, OvHV-2, Rhadinovirus, viroses.

\section{INTRODUCTION}

Malignant catarrhal fever (MCF) is an infectious, pansystemic, usually fatal disease of several species of cattle and sheep (Kleiboeker et al. 2002), with wide geographic distribution caused by a Rhadinovirus, an ovine herpesvirus 2 (OvHV-2), in the family Gammaherpesvirinae (Plowright 1990). The wide range of natural hosts for MCF can be divided into two categories: reservoir hosts (sheep, goat and gnu) and clinically susceptible hosts (cattle, bison and deer) (Li et al. 2011).

Currently, ten viruses in the group of those that cause MCF were identified, and six of them are proven associated with the clinical condition. The main agent of MCF is the OvHV-2, associated with sheep (sheep associated MCF), and the Alcelaphine herpesvirus 1 (AlHV-1), associated with the gnu (gnu associated MCF). In Brazil, MCF is associated with the contact of susceptible animals with sheep, when they eliminate OvHV-2, especially in pre and postpartum periods. In Africa, MCF is associated to the gnu (Connochaetes spp.), which is the reservoir host of AlHV-1 (Garmatz et al. 2004, Li et al. 2011).

The incubation period of MCF in cattle can vary from three to ten weeks; however, since it is a herpesvirus, it ranges according to the state of viral latency. The clinical course can last from three to seven days (O'Toole \& Li 2014). There are several clinical signs of MCF, and they affect many systems; they include fever, catarrhal nasal discharge, bilateral conjunctival congestion, sialorrhea, corneal opacity, blindness, bilateral epiphora, ulcers in the oral mucosa and nostrils (Galiza et al. 2010), incoordination, muscle trembling and pedaling movements (Sanches et al. 2000), crusting dermatitis, lymphadenomegaly, leptomeningeal hyperemia (Peixoto et al. 2015) and tongue and palate epithelium detachment (Döbereiner \& Tokarnia 1959, Galvão et al. 2016).

Gross lesion include ulcers in the oral cavity, tongue, esophagus, and upper respiratory tract (Galiza et al. 2010), accentuated pulmonary edema, necrosis in the extremity of the conical papillae in the cheek, and kidneys with multiple white spots (Galvão et al. 2016). Microscopically, there are lymphocytes and macrophages that infiltrate the arterial medius and adventitia, associated with fibrinoid necrosis (Sanches et al. 2000, Peixoto et al. 2015), interstitial nephritis composed of macrophages and lymphocytes, and marked hyperplasia and necrosis of lymphoid follicles (Peixoto et al. 2015, Galvão et al. 2016).
The Asian deer, from the species Rusa unicolor (Kerr, 1792) (=Cervus unicolor) is native from the forests of countries like Bangladesh, China, Cambodia, India, Indonesia, Malaysia, Sri Lanka, Taiwan, Thailand and Vietnam. Currently, this species is considered vulnerable by the red list of the International Union for Conservation of Nature (Timmins et al. 2015). This paper reports the epidemiological, clinical and pathological findings of a MCF outbreak in deer from the Rusa unicolor species in the State of Rio de Janeiro.

\section{MATERIALS AND METHODS}

The clinical history was obtained from interviews with the animal scientist in charge of the conservationist farm where the outbreak of malignant catarrhal fever (MCF) took place. One female specimen of Sambar deer (Rusa unicolor), aged approximately three years, with clinical neurological signs, died during contention and was referred for necropsy in the Setor de Anatomia Patológica (SAP 33865) at Universidade Federal Rural do Rio de Janeiro (UFRRJ). During necropsy, $10 \mathrm{ml}$ of cerebrospinal fluid was sampled from the atlanto-occipital space for analysis and sent to the Laboratório de Patologia Clínica at Universidade Castelo Branco/RJ (Stokol et al. 2009). Fragments of several organs were fixated in $10 \%$ buffered formalin and processed for the histological examination, stained with hematoxylin eosin (HE) and examined using optical microscopy.

Fragments of telencephalic occipital lobe, cerebellum and bulb were collected and stored at $-20^{\circ} \mathrm{C}$ for the conduction of PCR in the Laboratorio de Biologia Molecular of Universidade Federal de Mato Grosso. For the PCR, samples of DNA were extracted from the fresh nervous system using the standard method of proteinase $\mathrm{K} / \mathrm{phenol} /$ chloroform extraction and ethanol precipitation (Sambrook \& Russel 2001). The primer pairs used were 556 (AGTCTGGG-TATATGAATCCAGATGGCTCTC) and 755 (AAGATAAGCA-CCAGTTATGCATCTGATAAA). A total of $8 \mu$ l of each product of PCR was assessed in $2 \%$ agarose gel containing ethidium bromide, being analyzed with a transilluminator (Baxter et al. 1993).

\section{RESULTS}

This outbreak of malignant catarrhal fever (MCF) in Sambar deer took place in March, 2017, in a conservationist property in the city of Casimiro de Abreu/RJ. The first specimens that composed the initial group of deer were acquired in the State of Goiás. The pastures were restructured to receive this herd in 2011. About two months before the deer arrived, the sheep were placed in the location while it was still being reconstructed. Then, the deer were placed inside this location with the meat sheep, which were often slaughtered after about 80 days. During the outbreak, there were 15 meat sheep (eight-castrated male and seven female) sharing pastures and drinking fountains. In the same farm, in other locations, there were other wild species like tapirs (Tapirus terrestris), axis deer (Axis axis), fallow deer (Dama dama) and the indian antelope (Antilope cervicapra). Many species of wild and domestic birds, besides equines, cattle, buffalos and dogs were also bred in the farm.

Of the 23 deer in this farm, 19 died with similar clinical signs, characterized by incoordination, ataxia, falls and difficulties to get up. The evolution of the disease happened in a maximum period of 48 hours; some deer were found dead in the pasture. In a period of 28 days, 19 deer died. After the people in charge of the flock were informed of the diagnosis of MCF, the owner performed euthanasia in four deer before 
the presentation of any clinical sign. The morbidity and mortality of MCF in this outbreak was $82.6 \%(19 / 23)$, and lethality rate was $100 \%$.

One female Sambar deer (Rusa unicolor), aged approximately three years, presented with incoordination, walking around in circles, falling and having difficulties to move. It had opisthotonos, ataxia and dry nostrils. This deer died during contention. The external examination showed round, irregular red signs of alopecia on the skin, in the scapular region and the flank. The udder was developed, firm, with multiple petechial or ecchymotic hemorrhage on the skin (Fig.1). In the internal examination, the mammary gland presented great amounts of milk secretion and moderate amounts of purulent exudate. The uterus had a $20 \mathrm{~cm}$ long female fetus.

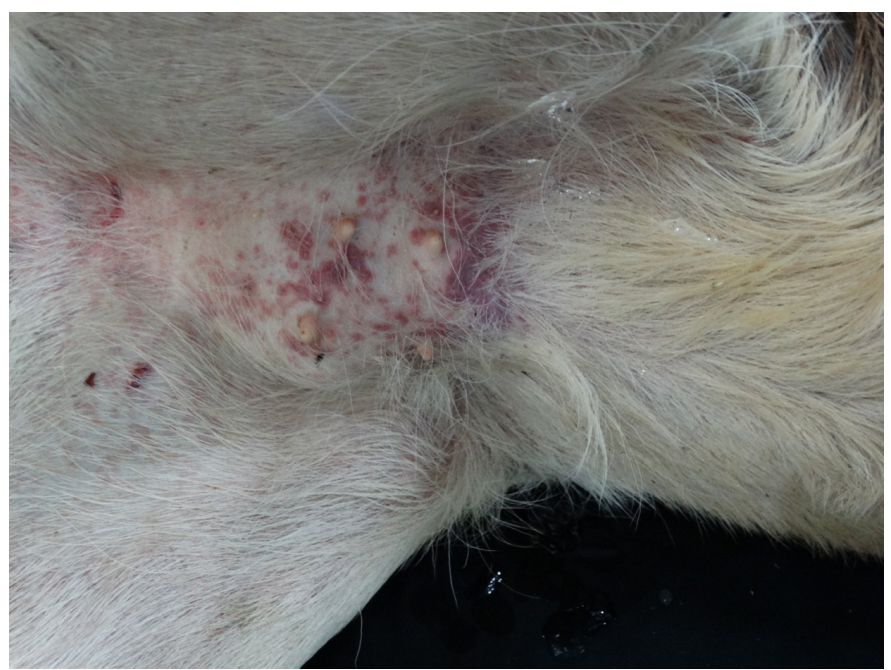

Fig.1. Malignant catarrhal fever in Sambar deer (Rusa unicolor). The udder skin has multiple petechial or ecchymotic hemorrhage.
The trachea presented marked amount of frothy edema. The lungs showed marked congestion and edema. The kidneys were diffusely dark red and the capsular surface had multiple white spots measuring 1-2mm. Histologically, in the brain (frontal, parietal, temporal, occipital cortex, cerebellum and bulb), and spinal cord (cervical, thoracic and lumbar) presented with perivascular and meningeal inflammatory infiltrate, composed of lymphocytes and other undifferentiated mononuclear cells with moderate pleomorphism. Plasma cells and macrophages were occasionally observed and rarely neutrophils (Fig.2A). The endothelial cells were activated, and several vessels showed moderate to accentuated number of eosinophilic clots, which characterized meningoencephalitis with fibrinoid vasculitis (Fig.2B). The thalamus and the lateral ventricle showed fibrinoid vasculitis, and the choroid plexus had interstitial thickening, with infiltration by lymphocytes and plasma cells. Both eyes presented with accentuated and diffuse lymphohistiocytic choroiditis, and moderate and focal lymphohistiocytic keratitis; one of the eyes had retinal detachment. The rete mirabile presented with vasculitis with infiltrate of lymphocytes, plasma cells and, in rare vessels, there was a small number of eosinophilic clots similar to fibrin. The nasal conchae showed fibrinoid vasculitis and thickening of the mucosa due to an infiltrate composed by lymphocytes and neutrophils; in the lungs, there was thickening of the alveolar septa which were infiltrated by lymphocytes. The kidneys had a multifocal periglomerular interstitial inflammatory infiltrate composed of lymphocytes. The lymph nodes showed increased lymphocytic cellularity, multifocal and moderate histiocytic infiltrate and thickened nodal capsule due to an infiltrate composed of lymphocytes. The spleen showed diffuse and accentuated white pulp depletion. In the intestines, there was accentuated and diffuse inflammatory infiltrate, composed of lymphocytes in the mucosa and, occasionally, in the submucosa. In the skeletal muscle, between the fibers, there was a mild multifocal lymphocytic infiltrate. The skin had superficial
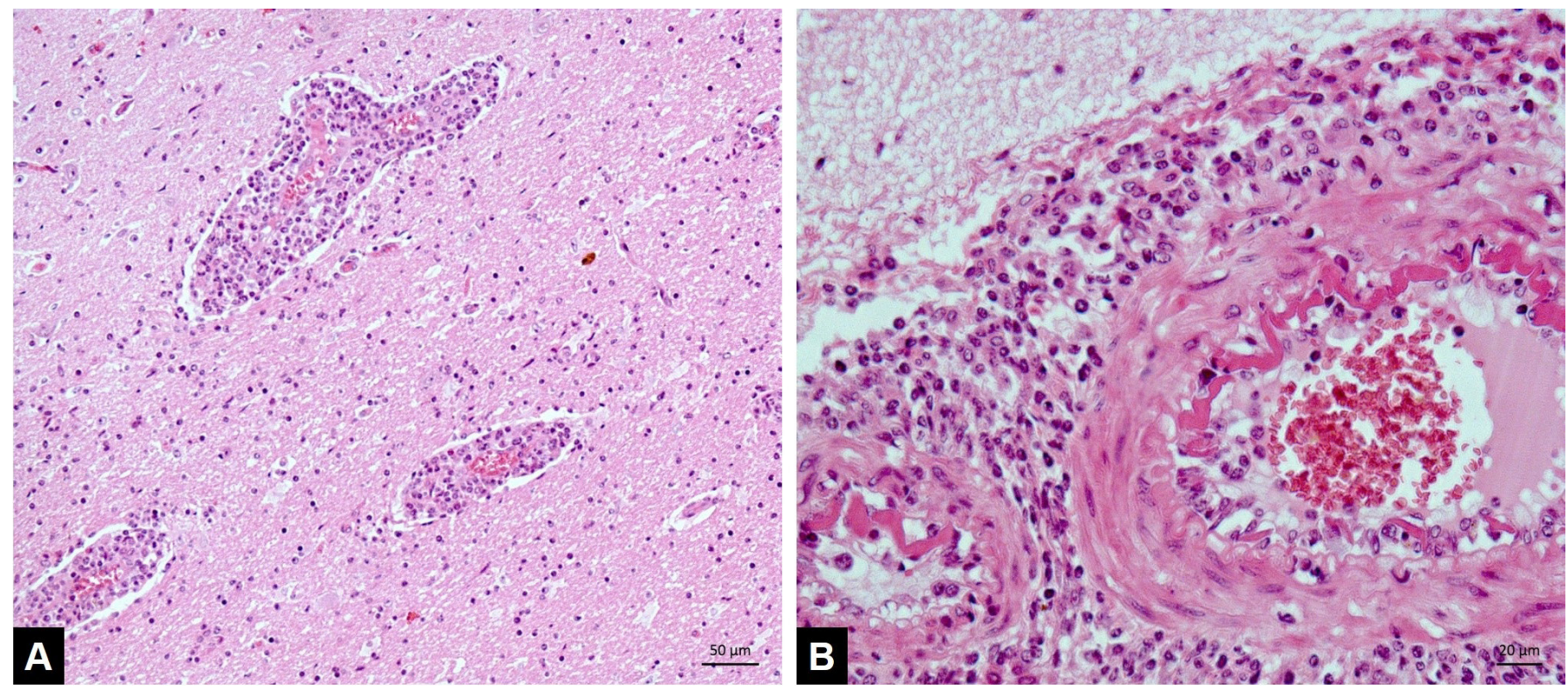

Fig.2. Malignant catarrhal fever in Sambar deer (Rusa unicolor). (A) Cerebral cortex with perivascular mononuclear inflammatory infiltrate. HE, obj.20x. (B) Fibrinoid vasculitis in arterioles in the subarachnoid space of the cerebral cortex. HE, obj.40x. 
pustule in the stratum corneum; and the superficial dermis had infiltrate of lymphocytes and macrophages.

The cerebrospinal fluid was fuzzy, had $450 \mathrm{mg} / \mathrm{dl}$ of protein, was negative for glucose and had 1,230cells/ $\mu \mathrm{l}$, being $83 \%$ of lymphocytes. The samples of nervous tissue were positive in PCR, with amplification of the molecular fragment of $231 \mathrm{pb}$.

\section{DISCUSSION}

The diagnosis of the present outbreak of malignant catarrhal fever (MCF) in Sambar deer was established based on the epidemiological, clinical, pathological findings and on the molecular amplification of the viral DNA of the ovine herpesvirus 2 (OvHV-2), using the polymerase chain reaction technique (PCR). This outbreak is similar to findings in other MCF cases in deer (Brown \& Bloss 1992, Tomkins et al. 1997, Driemeier et al. 2002, Kleiboeker et al. 2002, Li et al. 2011, Palmer et al. 2013).

MCF has been reported in about 13 cervid species ( 0 'Toole \& Li 2014). Clark et al. (1970) mentioned the occurrence of MCF outbreaks in deer, unlike the disease affecting the cattle species, which often takes place in isolated cases. In this case, the deer lived in a location together with sheep, which is compatible with the epidemiology of this condition (Garmatz et al. 2004), however, the placental transfer has been reported as a form of transmission in cattle (Plowright 1990, Headley et al. 2015), besides the possibility of virus carriage through birds that feed in the feeders (Li et al. 2008). The presence of other deer that were not affected by MCF in this outbreak, like the Axis deer (Axis axis) and the Fallow deer (Dama dama) in locations close to where the affected deer were staying, probably reveals a lower predisposition of those species to MCF in comparison with the Sambar deer (Rusa unicolor). Likely, O'Toole \& Li (2014) discuss that Fallow deer (D. dama) are relatively resistant. The considered highly susceptible cervid species are particularly white-tailed deer (Odocoileus virginianus) and Père David's deer (Elaphurus davidianus). The Moose (Alces alces) and elk (Cervus canadensis) appear to be moderately susceptible (Brown \& Bloss 1992, Kleiboeker et al. 2002, Palmer et al. 2013, 0’Toole \& Li 2014).

In this MCF outbreak, the evolution of the neurological signs was hyperacute, in a maximum period of 48 hours, and some deer were found dead. The evolution of MCF in deer (Mazama gouazoubira) that occurred in Cuiabá/MT, Brazil, took from two to three days (Driemeier et al. 2002). In deer, the condition is usually acute or hyperacute, and the deer often die before developing the classic typical signs of the disease (Wobeser et al. 1973, Tomkins et al. 1997). There were similarities in a MCF outbreak that happened in a zoo in Rome, Italy, where 11 deer (Sika deer) died from the hyperacute form of the disease 12-48 hours after the onset of the clinical signs. In this case, goats and sheep were disease reservoirs (Frontoso et al. 2016). This short period of the clinical course explains how, sometimes, there are few clinical symptoms in deer, unlike in cattle, in which the clinical evolution is longer (Tomkins et al. 1997). In the USA, $26(100 \%)$ white-tailed deer (O. virginianus) bred in captivity died, and, of these, 11 did not present with any clinical signs (Palmer et al. 2013).

The MCF outbreak in the state of Mato Grosso was peculiar; the deer (M. gouazoubira) were separated from the wool sheep only by a zoo fence (Driemeier et al. 2002). In this case, the deer ( $R$. unicolor) and the sheep shared the same location and and drinking fountains. Brown \& Bloss (1992) described an outbreak of MCF in 23 white-tailed deer (O. virginianus), some were bred free, and others had contact with sheep and goats at a distance of 100 to 200 meters.

A study conducted with deer and wild goats infected with the MCF virus, without clinical disease, revealed that the virus could circulate in lower doses and result in latent infection (Frontoso et al. 2016). To confirm the possibility of latent infection in deer, the DNA of OvHV-2 was detected in the blood of $72 \%(23 / 32)$ of the deer that were clinically normal (Palmer et al. 2013). This explains the variation in the length of the incubation period, as well as the duration of the clinical signs. In this case, the sheep and the deer lived in the same location for six years. After the clinical manifestation in one deer, the disease rapidly spread in the flock.

This report of MCF in deer ( $R$. unicolor) stands out for the clinical signs, especially neurological ones, and for the absence of ulcerative lesions in the gastrointestinal tract, which is different from the outbreak reported by Driemeier et al. (2002), who found mild necrosis in the oral and nasal mucosa of deer (M. gouazoubira). Likely described in this report, other lesions in deer, than neurological include congestion and petechial or ecchymotic hemorrhage in multiple tissues, lymphocytic vasculitis in multiple organs and lymph nodes with lymphoid hyperplasia (Brown \& Bloss 1992, O’Toole \& Li 2014).

According to the World Organization for Animal Health, (OIE 2013), the histological changes have been essential to confirm cases of MCF, and are characterized by degeneration, fibrinoid vasculitis with infiltration of lymphoid cells in the tunica adventitia, associated with eosinophilic material similar to fibrin, especially in brain vessels, besides hyperplasia and necrosis of lymphoid organs. The lesion of the central nervous system of the deer in this case is in accordance with the findings in other MCF described in cervid species (Brown \& Bloss 1992, Tomkins et al. 1997, Driemeier et al. 2002, Kleiboeker et al. 2002, Li et al. 2011, Palmer et al. 2013).

The cerebrospinal fluid test showed large amount of lymphocytes that are compatible with a viral infection (Stokol et al. 2009). PCR is an important diagnostic tool to prove which species of virus is involved (Driemeier et al. 2002, Li et al. 2011). In the current outbreak, samples of encephalic tissue showed DNA of ovine herpesvirus 2 (OvHV-2). The association of PCR and the histopathology allow excluding the differential diagnoses. Clostridial enteritis, epizootic hemorrhagic disease/bluetongue, adenoviral infection, and yersiniosis are considered as MCF-like signs in deer (Driemeier et al. 2002, Li et al. 2011, O’Toole \& Li 2014). Clinical samples to detect OvHV-2 by PCR can be collected via nasal swab and blood (Frontoso et al. 2016). The spleen is an excellent organ to obtain samples during necropsy for molecular examination; in the outbreak in which 26 white-tailed deer (O. virginianus) died, the PCR amplified the DNA of OvHV-2 in spleen samples of all deer (Palmer et al. 2013).

In a retrospective study of diseases from the central nervous system in domestic ruminants in Rio Grande do Sul, 3.28\% of the cases $(10 / 305)$ were diagnosed with MCF (Sanches et al. 2000). Similar studies were conducted with cattle in Mato Grosso do Sul, and of the 341 diagnoses corresponding to neurological diseases, only $0.37 \%$ corresponded to MCF (Ribas et al. 2013). In the Northeastern semiarid, of the 
411 necropsies of cattle, $6.3 \%$ were MCF (Galiza et al. 2010). In another study, of 1,124 cases of diagnoses in cattle, eight cases were of MCF, representing $2.6 \%$ of the inflammatory diseases diagnosed in Mato Grosso (Rondelli et al. 2017).

MCF is well documented in cattle in Latin America. Diagnoses were carried out in Uruguay (Preliasco et al. 2013). In Brasil, there were reported cases of MCF in cattle in the Northeast (Döbereiner \& Tokarnia 1959, Macêdo et al. 2007, Peixoto et al. 2015), Mid-West (Mendonça et al. 2008, Furlan et al. 2012, Lemos et al. 2005, Ribas et al. 2013), Southeast (Lemos et al. 2005, Martins et al. 2017, Galvão et al. 2016) and South region (Barros et al. 1983, Garmatz et al. 2004, Rech et al. 2005). In buffaloes, MCF was diagnosed in Minas Gerais (Costa et al. 2009).

Considering the importance of this condition in cattle around the world, Lankester et al. (2016) have recently studied the possibility of vaccination to immunize cattle against AIHV-1, which resulted in the induction of specific antibodies. The PCR with blood samples detected viral DNA in both groups of cattle, but the frequency of the infection was significantly lower in the vaccinated groups. This allows inferring that, in future, the disease can be controlled with vaccines. The prophylaxis of MCF is to perform the isolation between the asymptomatic carrier species and the susceptible species (Döbereiner \& Tokarnia 1959, Li et al. 2011).

\section{CONCLUSIONS}

The epidemiological, clinical, macroscopic, histological and molecular findings reported in the deer (Rusa unicolor) with malignant catarrhal fever (MCF) in this analysis were similar to the other deer. The neurological clinical signs and lesions stood out.

MCF in deer seems to present higher morbidity in comparison to MCF in cattle. It is important to mention the MCF in the list of differential diagnoses of diseases that present with nervous symptomatology in deer.

\section{REFERENCES}

Barros S.S., Santos M.N. \& Barros C.S.L. 1983. Surto de febre catarral maligna em bovinos no Rio Grande do Sul. Pesq. Vet. Bras. 3:81-86.

Baxter S.I., Pow I., Bridgen A. \& Reid H.W. 1993. PCR detection of the sheepassociated agent of malignant catarrhal fever. Arch. Virol. 132(1/2):145-159. <http://dx.doi.org/10.1007/BF01309849><PMid:8352654>

Brown C.C. \& Bloss L.L. 1992. An epizootic of malignant catarrhal fever in a large captive herd of white-tailed deer (Odocoileus virginianus). J. Wildl. Dis. 28(2):301-305. <http://dx.doi.org/10.7589/0090-3558-28.2.301> <PMid:1602586>

Clark K.A., Robinson R.M., Marburger R.G., Jones L.P. \& Orchard J.H. 1970. Malignant catarrhal fever in Texas cervids. J. Wildl. Dis. 6(4):376-383. <http://dx.doi.org/10.7589/0090-3558-6.4.376> <PMid:16512141>

Costa E.A., Bastianetto E., Vasconcelos A.C., Bomfim M.R.Q., Fonseca F.G., Gomes A.D., Leite R.C. \& Resende M. 2009. Surto de febre catarral maligna (FCM) em búfalos da raça Murrah no estado de Minas Gerais. Pesq. Vet. Bras. 29(5):395-400. <http://dx.doi.org/10.1590/S0100-736X2009000500006>

Döbereiner J. \& Tokarnia C.H. 1959. Ocorrência da coriza gangrenosa dos bovinos no município de Serra Negra do Norte, Rio Grande do Norte. Arqs Inst. Biol. Anim., Rio de J., 2:65-82.

Driemeier D., Traverso S.D., Cattani C., Cruz C.E.F. \& Brito M.F. 2002. Outbreak of malignant catarrhal fever in brown brocket deer (Mazama gouazoubira) in
Brazil. Vet. Rec. 151(9):271-272. <http://dx.doi.org/10.1136/vr.151.9.271> $<$ PMid:12233830>

Frontoso R., Autorino G.L., Friedrich K.G., Li H., Eleni C., Cocumelli C., Di Cerbo P., Manna G. \& Scicluna M.T. 2016. An acute multispecies episode of sheep-associated malignant catarrhal fever in captive wild animals in an italian zoo. Transb. Emer. Dis. 63(6):621-627. <http://dx.doi.org/10.1111/ tbed.12321><PMid:25598396>

Furlan F.H., Amorim T.M., Justo R.V., Mendes E.R.S., Zilio M.G., Costa F.L., Nakazato L. \& Colodel E.M. 2012. Febre catarral maligna em bovinos no norte de Mato Grosso, Brasil. Acta Scient. Vet. 40(2):1043.

Galiza G.J.N., Silva M.L.C.R., Dantas A.F.M., Simões S.V.D. \& Riet-Correa F. 2010. Doenças do sistema nervoso de bovinos no semiárido Nordestino. Pesq. Vet. Bras. 30(3):267-276. <http://dx.doi.org/10.1590/S0100736X2010000300014>

Galvão A., Galvão C.F., Caldas S.A., dos Santos A.M., d'Avila M.S., Cid G. de C., Nogueira V.A. \& Peixoto T.C. 2016. Febre catarral maligna em bovino no estado do Rio de Janeiro: relato de caso. Revta Bras. Med. Vet. 38(Supl.):108-114.

Garmatz S.L., Irigoyen L.F., Rech R.R., Brown C.C., Zhang J. \& Barros C.S.L. 2004. Febre catarral maligna em bovinos no Rio Grande do Sul: transmissão experimental para bovinos e caracterização do agente etiológico. Pesq. Vet. Bras. 24(2):93-103.<http://dx.doi.org/10.1590/S0100-736X2004000200009>

Headley S.A., Pimentel L.A., Oliveira V.H., Toma H.S., Alfieri A.F., Carvalho A.M., Santos M.D. \& Alfieri A.A. 2015. Transplacental transmission of ovine herpesvirus 2 in cattle with sheep-associated malignant catarrhal fever. J. Comp. Pathol. 153(4):206-211. <http://dx.doi.org/10.1016/j. jсра.2015.10.175><PMid:26604083>

Kleiboeker S.B., Miller M.A., Schommer S.K., Ramos-Vara J.A., Boucher M. \& Turnquist S.E. 2002. Detection and multigenic characterization of a herpesvirus associated with malignant catarrhal fever in white-tailed deer (Odocoileus virginianus) from Missouri. J. Clin. Microbiol. 40(4):1311-1318. <http://dx.doi.org/10.1128/JCM.40.4.1311-1318.2002><PMid:11923350>

Lankester F., Russell G.C., Lugelo A., Ndabigaye A., Mnyambwa N., Keyyu J., Kazwala R., Grant D., Percival A., Deane D., Haig D.M. \& Cleaveland S. 2016. A field vaccine trial in Tanzania demonstrates partial protection against malignant catarrhal fever in cattle. Vaccine 34(6):831-838. <http://dx.doi. org/10.1016/j.vaccine.2015.12.009 ><PMid:26706270>

Lemos R.A.A., Rech R.R., Guimarães E.B., Kadri A. \& Dutra I.S. 2005. Febre catarral maligna em bovinos do Mato Grosso do Sul e de São Paulo. Ciência Rural 35(4):932-934. <http://dx.doi.org/10.1590/S0103-84782005000400030>

Li H., Cunha C.W. \& Taus N.S. 2011. Malignant catarrhal fever: understanding molecular diagnostics in context of epidemiology. Int. J. Mol. Sci. 12(10):68816893. <http://dx.doi.org/10.3390/ijms12106881> <PMid:22072925>

Li H., Karney G., O’Toole D. \& Crawford T.B. 2008. Long distance spread of malignant catarrhal fever virus from feedlot lambs to ranch bison. Can. Vet. J. 49(2):183-185. < PMid:18309750>

Macêdo J.T.S.A., Riet-Correa F., Simões S.V.D., Dantas A.F.M. \& Nobre V.M.T. 2007. Febre catarral maligna em bovinos na Paraíba. Pesq. Vet. Bras. 27(7):277-281. <http://dx.doi.org/10.1590/S0100-736X2007000700004>

Martins M.S.N., Castro A.M.M.G., Lima M.D.S., Pinto V.D.S.C., Silva T.G.D., Fava C.D., Depes C.R., Okuda L.H. \& Pituco E.M. 2017. Malignant Catarrhal Fever in Brazilian cattle presenting with neurological syndrome. Braz. J. Microbiol. 48(2):366-372.<http://dx.doi.org/10.1016/j.bjm.2016.10.021> $<$ PMid:28081979>

Mendonça F.S., Dória R.G.S., Schein F.B., Freitas S.H., Nakazato L., Boabaid F.M., Paula D.A.J., Dutra V. \& Colodel E.M. 2008. Febre catarral maligna em bovinos no estado de Mato Grosso. Pesq. Vet. Bras. 28(3):155-160. <http:// dx.doi.org/10.1590/S0100-736X2008000300005>

O'Toole D. \& Li H. 2014. The pathology of malignant catarrhal fever, with an emphasis on Ovine Herpesvirus 2. Vet. Pathol. 51(2):437-452. <http:// dx.doi.org/10.1177/0300985813520435><PMid:24503439> 
OIE 2013. Malignant Catarrhal Fever. OIE Terrestrial Manual, World Organization for Animal Health, Paris.

Palmer M.V., Thacker T.C., Madison R.J., Koster L.G., Swenson S.L. \& Li H. 2013. Active and latent ovine herpesvirus-2 (OvHV-2) infection in a herd of captive white-tailed deer (Odocoileus virginianus). J. Comp. Pathol. 149(2/3):162166. <http://dx.doi.org/10.1016/j.jcpa.2013.01.005><PMid:23453492>

Peixoto T.C., Cunha V.A.F., Silva D.N., Farias S.S. \& Madureira K.M. 2015. Febre catarral maligna em bovino no estado da Bahia. Enciclop. Biosfera 11(21):1092-1101.

Plowright W. 1990. Malignant catarrhal fever virus, p.123-150. In: Dinter Z. \& Morein B. (Eds), Virus Infections of Ruminants. Elsevier Science Publishing, New York. <http://dx.doi.org/10.1016/B978-0-444-87312-5.50023-0>

Preliasco M., Easton M.C., Paullier C., Rivero R., Moraes D.F.S.D., Godoy I., Dutra V. \& Nakazato L. 2013. Diagnóstico de febre catarral maligna em bovinos do Uruguai. Pesq. Vet. Bras. 33(1):52-56. <http://dx.doi.org/10.1590/ S0100-736X2013000100010>

Rech R.R., Schild A.L., Driemeier D., Garmatz S.L., Oliveira F.N., Riet-Correa F. \& Barros C.S.L. 2005. Febre catarral maligna em bovinos no Rio Grande do Sul: epidemiologia, sinais clínicos e patologia. Pesq. Vet. Bras. 25(2):97-105. <http://dx.doi.org/10.1590/S0100-736X2005000200006>

Ribas N.L.K.S., Carvalho R.I., Santos A.C., Valençoela R.A., Gouveia A.F., Castro M.B., Mori A.E. \& Lemos R.A.A. 2013. Doenças do sistema nervoso de bovinos no Mato Grosso do Sul: 1082 casos. Pesq. Vet. Bras. 33(10):1183-1194. <http://dx.doi.org/10.1590/S0100-736X2013001000003>
Rondelli L.A.S., Silva G.S., Bezerra K.S., Rondelli A.L.H., Lima S.R., Furlan F.H., Pescador C.A. \& Colodel E.M. 2017. Doenças de bovinos no estado de Mato Grosso diagnosticadas no laboratório de patologia veterinária da UFMT (2005-2014). Pesq. Vet. Bras. 37(5):432-440.<http://dx.doi.org/10.1590/ s0100-736x2017000500002>

Sambrook J. \& Russel D.W. 2001. Molecular Cloning: a laboratory manual. Cold Spring Harbor Laboratory, New York

Sanches A.W.D., Langohr I.M., Stigger A.L. \& Barros C.S.L. 2000. Doenças do sistema nervoso central em bovinos no Sul do Brasil. Pesq. Vet. Bras. 20(3):113-118. <http://dx.doi.org/10.1590/S0100-736X2000000300005>

Stokol T., Divers T.J., Arrigan J.W. \& McDonough S.P. 2009. Cerebrospinal fluid findings in cattle with central nervous system disorders: a retrospective study of 102 cases (1990-2008). Vet. Clin. Pathol. 38(1):103-112. <http:// dx.doi.org/10.1111/j.1939-165X.2008.00094.x> <PMid:19228366>

Timmins R., Kawanishi K., Giman B., Lynam A., Chan B., Steinmetz R., Sagar Baral H. \& Samba Kumar N. 2015. Rusa unicolor. The IUCN Red List of Threatened Species, Cambridge.

Tomkins N.W., Jonsson N.N., Young M.P., Gordon A.N. \& McColl K.A. 1997. An outbreak of malignant catarrhal fever in young rusa deer (Cervus timorensis). Aust. Vet. J. 75(10):722-723.<http://dx.doi.org/10.1111/j.1751-0813.1997. tb12253.x><PMid:9406629>

Wobeser G., Majka J. \& Mills J. 1973. A disease resembling malignant catarrhal fever in captive white-tailed deer in Saskatchewan. Can. Vet. J. 14(5):106109. <PMid:4735750> 